\title{
PENERAPAN PENDIDIKAN AKHLAK MULIA DALAM MENGEMBANGKAN KARAKTER MELALUI METODE BERCERITA PADA ANAK USIA DINI (Studi Pada PAUD Non Formal An-Nuur)
}

\author{
Asep Saepudin ${ }^{1}$, Cahny Sudiarni ${ }^{*}$ ) \\ (aspudin@gmail.com)
}

\begin{abstract}
This study examines the application of noble character education in developing character through storytelling in early childhood in early childhood PAUD An-Nuur. The purpose of research is to obtain data on: 1) the implementation of the application of noble character education in developing character in early childhood in early childhood PAUD An-Nuur; 2) procedures for using storytelling in early childhood in the learning process in early childhood An-Nuur; 3) factors supporting and inhibiting the application of noble character education in developing character in early childhood in early childhood PAUD An Nuur.

The results of the application of noble character education with the extent of the benefit of knowledge, attitudes, procedures use storytelling that students get as leamers and their implementation in everyday life at school. To answer these problems the approach used in this study is a qualitative approach, the research procedure that produces descriptive data in the form of words written or spoken of people and observed behavior. Data collection techniques used were observation, interviews, documentation and study of literature. Research subjects in this study amounted to five informants, ie one person PAUD An Nuur, one early childhood tutor An Nuur, three students PAUD An Nuur.

Based on data processing and discussion, the result of research on the application of noble character education in early childhood in early childhood PAUD An-Nuur, have the same goal, for the good of the child and make the child is given habituation noble with good morals. starts with giving good advice to exemplify good life so that children can imitate exemplary.
\end{abstract}

Keywords: application of noble character education, character, storytelling

\section{A. Pendahuluan}

Pendidikan merupakan kebutuhan manusia sepanjang hayat. Setiap manusia membutuhkan pendidikan, sampai kapan pun dan dimana pun ia berada. Pendidikan sangat penting artinya, sebab tanpa pendidikan manusia sekarang, tidak akan berbeda dengan generasi manusia masa lampau, bahkan mungkin juga malah lebih rendah, lebih jelek kualitasnya. Oleh karena itu, dapat dikatakan bahwa majumundurnya atau baik buruknya peradaban masyarakat suatu bangsa akan ditentukan oleh pendidikan yang ditempuh oleh masyarakat tersebut.menurut ilmu dalam agama Islam wajib bagi setiap umat, baik laki-laki maupun perempuan, karena pendidikan berusaha membentuk pribadi berkualitas, baik jasmani maupun rohani.
Dengan demikian pendidikan mempunyai peran strategis dalam membentuk anak didik menjadi manusia berkualitas, tidak saja berkualitas dalam segi kognitif, afektif, psikomotorik, tetapi juga aspek spiritual. Hal ini membuktikan pendidikan mempunyai andil besar dalam mengarahkan anak didik untuk mengembangkan diri berdasarkan bakat dan potensinya. Melalui pendidikan, memungkinkan anak menjadi pribadi sholeh, pribadi berkualitas secara skill, kognitif, dan spiritual.

Setiap makhluk Allah yang dilengkapi dengan akal wajib untuk menuntut ilmu apa saja, yang pada intinya semua ilmu itu adalah baik. Hanya karena ulah manusialah yang menyebabkan ada golongan ilmu yang tidak baik. Itu semua tergantung dari manusia sendiri dalam 
mempergunakannya, apakah untuk hal kebaikan ataupun untuk kejahatan.

Tahun-tahun pertama kehidupan anak atau yang sering dikenal dengan usia dini merupakan masa yang sangat tepat untuk meletakkan dasar-dasar pengembangan kemampuan anak, karena usia (0 - 6 tahun) merupakan periode atau masa keemasan (The Golden Age) bagi pertumbuhan dan perkembangan anak, selain gizi yang cukup beragam stimulus juga harus diberikan. Oleh karena itu, keterlibatan orang tua dan pendidik pada masa ini sangat baik untuk mengetahui, memehami dan mengerti perkembangan anak usia dini (Riyanto, 2005:6-7).

Pendidikan di sekolah merupakan kelanjutan dalam keluarga. Sekolah merupakan lembaga tempat dimana terjadi proses sosialisasi yang kedua setelah keluarga, sehingga mempengaruhi pribadi anak dan perkembangan sosialnya. Disekolah anak akan belajar apa yang ada di dalam kehidupan, dengan kata lain sekolah harus mencerminkan kehidupan sekelilingnya. Oleh karena itu, sekolah tidak boleh dipisahkan dari kehidupan dan kebutuhan masyarakat sesuai dengan perkembangan budidayanya. "Dalam kehidupan modern seperti saat ini, sekolah merupakan suatu keharusan karena tuntutan-tuntutan yang diperlukan bagi perkembangan anak sudah tidak memungkinkan akan dapat dilayani oleh keluarga". (Sudrajat, 2008).

Tetapi realitas dimasyarakat membuktikan pendidikan di sekolah belum mampu menghasilkan anak didik berkualitas secara keseluruhan, kenyataan ini dapat dicermati dengan banyaknya prilaku kurang terpuji dimasyarakat, sebagai contoh merebaknya penggunaan narkoba, perampokkan, bunuh diri, pelecehan seksual, anak usia dini sudah terbiasa merokok dan banyak lagi. Realitas ini memunculkan anggapan bahwa pendidikan gagal membentuk anak didik berakhlak mulia.

Pembelajaran akhlak penting sekali ditanamkan pada anak didik sejak usia dini, karena pada usia ini anak mudah sekali meniru apa yang mereka lihat dan dengar pasti akan melekat di memori anak usia dini. Jika anak tidak dibina dengan pembelajaran akhlak terpuji sedini mungkin, maka pada masa perkembangan anak menuju kedewasaan akan membawa dampak yang lebih fatal lagi dan akan meresahkan masyarakat sekitarnya. Anak itu adalah amanat bagi kedua orang tuanya, hatinya yang bersih merupakan permata yang berharga, jika anak dibiasakan dan di didik kebaikan akan tumbuh dalam kebaikan dan berbahagia di dunia dan akhirat. Dan jika dibiasakan pada kejelekkan dan dibiarkan berperilaku binatang, akan celaka dan binasa, maka sebagai pencegahannya dengan pendidikan akhlak yang baik harus ditanamkan sejak usia dini.

Karakter memiliki makna lebih tinggi dari moral, karena karakter tidak hanya berkaitan dengan masalah benar dan salah, tetapi bagaimana menanamkan kebiasaan (habituation) tentang hal-hal yang baik dalam kehidupan, sehingga siswa memiliki kesadaran, kepekaan, dan pemahaman yang tinggi, serta kepedulian dan komitmen untuk menerapkan kebajikan dalam kehidupan sehari-hari. Dengan demikian dapat dikatakan bahwa orang yang berkarakter merupakan sifat alami seseorang dalam merespons situasi secara bermoral, yang diwujudkan dalam tindakkan nyata melalui perilaku baik, jujur, ikhlas, bertanggung jawab, hormat terhadap orang lain.

Karakter merupakan upaya untuk membantu perkembangan jiwa anak-anak baik lahir maupun batin, dari sifat kodratinya menuju ke arah peradaban yang manusiawi dan lebih baik dengan cara pendidikan yang menyenangkan.

Waktu yang paling menyenangkan pada usia dini adalah ketika sedang bermain. Kegiatan bermain adalah kegiatan apa saja dalam suasana yang menyenangkan. Menyenangkan adalah kata kunci dalam setiap kegiatan bagi anak. Tanpa suasana yang menyenangkan, 
kegiatan itu bagi anak tidak berarti apaapa, walaupun mungkin terbilang mahal. Oleh karena itu, orang tua dan pendidik dalam menciptakan kegiatan belajar, pelatihan atau pembiasaan hendaknya dalam suasana yang menyenangkan.

Dengan demikian tidak membebani, tidak memaksa dan tidak menjadikan mereka bersedih hati. "Kegiatan yang dilakukan secara spontan, tanpa paksaan, sesuai dengan gerak hati anak, dan mendatangkan kegembiraan harus diciptakan terus menerus secara bervariasi". (Riyanto, 2005:83). "Diselasela bermain, anak belajar memahami salah benar. Ia juga mulai belajar memahami apa itu adil jujur, menguasai jiwa, dan menanggalkan egoisme ketika bermain ramai-ramai, dan ia juga dapat belajar berjiwa besar". (AshShawwaf,2003:126).

Metode pembelajaran yang digunakan di Paud An Nuur ialah metode belajar yang menyenangkan bagi anak usia dini, salah satunya yaitu metode bercerita. Bercerita adalah menuturkan sesuatu yang mengisahkan tentang perbuatan atau suatu kejadian dan disampaikan secara lisan dengan tujuan membagikan pengalaman dan pengetahuan kepada orang lain. Bercerita juga merupakan salah satu strategi pembelajaran yang dapat memberikan pengalaman belajar bagi anak.

Aneka cerita yang diberikan ternyata dikemudian hari punya andil besar dalam pembentukan sifat dan sikap, ikut membangun karakter dan kepribadian, dengan kata lain bercerita dapat menyuntikkan aneka nilai dalam kehidupan anak, disaari atau tidak disadari cerita dapat memberikan banyak faedah dalam kehidupan anak. Bercerita dapat membentuk karakter, mengembangkan imajinasi, mengembangkan kreativitas, mengembangkan minat baca dan menulis, meningkatkan kemampuan bahasa dan lompetensi lainnya, juga dapat meningkatkan kecerdasan emosi. Bercerita kepada anak juga merupakan metode pendidikan yang sangat efektif dan efisien.

Berdasarkan keadaan empiris di lapangan, kondisi siswa siswi Paud AnNuur telah menerapkan pendidikan akhlak yang mulia dalam mengembangkan karakter yang harus dimiliki oleh anak sejak usia dini yaitu bersikap disiplin disekolah seperti anjuran atau suruhan terhadap anak-anak untuk duduk yang baik, tidak berteriak-teriak agar tidak mengganggu orang lain, bersih badan, rapih berpakaian, hormat terhadap orang tua, menyayangi teman, rapi dalam berbaris sebelum masuk kelas, mengucapkan salam dengan bersalaman kepada tutornya, berdoa sebelum dan sesudah belajar, berdoa sebelum dan sesudah makan, berdoa masuk dan keluar WC, sabar menunggu giliran, mau berbagi dan menolong terhadap teman, sholat berjamaah, berinfak di hari jumat uang dari hasil infak di pakai untuk menengok temannya yang sakit, bertanggung jawab dapat membereskan mainan sendiri, dapat membe dakan barang milik orang lain dan barang milik sendiri kegiatan semua itu berjalan secara intens if walaupun kadang ada satu atau dua anak yang belum bisa mengikuti kegiatan tersebut.

Penerapan pendidikan akhlak bagi anak-anak merupakan salah satu unsur penting dalam pendidikan agama, disamping pembinaan aqidah dan ibadah. Hal ini ditegaskan Nabi Muhammad SAW dalam sabdanya "sesungguhnyalah aku diutus untuk menyempurnakan akhlak". Penerapan akhlak pada dasarnya dimaksudkan sebagai upaya penanaman nilai-nilai Is lami sebagaimana tercermin dalam pola perilaku seseorang. Di dalam penyelenggaraan penerapan akhlak tersebut sedikitnya ada tiga sasaran yang patut mendapat perhatian yaitu: 1) pemahaman dan penghayatan tentang nila $\mathrm{i}$ akhlak, 2) keterampilan mengamalkannya, 3) kesadaran dan kesediaan untuk mengamalkannya dengan penuh disiplin.

Dari tiga sasaran tersebut diatas maka upaya untuk menumbuhkan sikap 
dan kesadaran mengamalkan nilai-nila i tersebut merupakan yang terpenting tetapi juga paling sulit, sehingga diperlukan latihan dan pembiasaan yang terus menerus dan dimulai sedini mungkin. Dengan demikian diharapkan suatu nilai yang baik telah dihayati penuh dalam hati tertanam dalam jiwa maka akan terus melekat sebagai bagian dari watak dan kepribadian si anak pada masa yang akan datang. Bekal utamanya adalah keyakinan dan keimanan kepada Allah SWT, hidup beradat, berakhlak mulia. Inilah, yang menjadi program utama dalam pendidikan anak usia dini (PAUD).

Berdasarkan uraian latar belakang di atas, mendorong penulis untuk mencari gambaran yang kongkrit dan membahas penelitian dengan judul "Penerapan Pendidikan Akhlak Mulia dalam Mengembangkan Karakter Melalui Metode Bercerita pada Anak Usia Dini di Paud An-Nuur". Sehingga dapat memberikan kontribusi bagi keberhasilan pendidikan pada umumnya dan keberhasilan penerapan akhlak mulia bagi anak usia dini.

\section{B. Tujuan dan Manfaat}

Tujuan dari penelitian ini untuk mendapatkan gambaran yang jelas tentang penerapan pendidikan akhlak mulia dalam menge mbangkan karakter melalui metode bercerita pada anak usia dini. Tujuan khususnya untuk mendapatkan data deskripsi tentang penerapan pendidikan akhlak mulia dalam mengembangkan karakter pada anak usia dini, prosedur penggunaan metode bercerita dalam proses pembelajaran, faktor pendukung dan penghambat penerapan pendidikan akhlak mulia dalam mengembangkan karakter melalui metode bercerita pada anak usia dini

Manfaat penelitian ini terdiri atas manfaat teoritis dan praktis. Secara teoritis penelitian ini diharapkan dapat menambah khazanah pengetahuan dalam bidang pendidikan anak usia dini. Manfaat teoritis hasil dari penelitian ini merupakan masukkan bagi perkembangan dunia keilmuan dalam meningkatkan teori-teori pembelajaran, manfaat praktis sebagai bahan masukan dalam melaksanakan tugas dan kewajiban oleh para tutor pendidikan anak usia dini, dalam pembelajaran penerapan pendidikan akhlak mulia dengan metode bercerita.

\section{Kajian Teori}

\section{Konse p Pendidikan Akhlak Mulia}

Pengertian pendidikan akhlak adalah usaha sadar dan tidak sadar yang dilakukan oleh seorang pendidik untuk membentuk tabiat yang baik pada seorang anak didik, sehingga terbentuk manusia yang taat kepada Allah. Pembentukan tabiat ini dilakukan oleh pendidik secara kontinyu dengan tidak ada paksaan dari pihak manapun.

Menurut Widodo "akhlak berarti budi pekerti, tingkah laku, perangai." Perkataan akhlak berasal dari perbendaharaan istilah-istilah Islamologi. Istilah lain yang mirip dengan akhlak adalah moral. Hakikat pengertian antara keduanya sangat berbeda. Moral berasal dari bahasa latin, yang mengandung arti laku perbuatan lahiriyah.

Kata akhlak berasal dari bahasa Arab "Akhlaaq" bentuk jama' dari kata "Khuluk" yang berarti tabiat, watak, perangai, dan budi pekerti Al Ghazali memberi batasan sebagai berikut: "Khuluk adalah hal ikhwal yang melekat dalam jiwa, darinya timbul perbuatan-perbuatan dengan mudah tanpa dipikir dan di teliti.

\section{Konsep karakter}

Menurut Wynne

(1991:3)

mengemukakan bahwa karakter berasal dari bahasa Yunani yang berarti "to mark" (menandai) dan memfokuskan pada bagian mana menerapkan nilai-nilai kebaikan dalam tindakkan nyata atau perilaku sehari-hari. Oleh sebab itu, seseorang yang berperilaku tidak jujur, curang, kejam dan rakus dikatakan sebagai orang yang 
memiliki karakter jelek, sedangkan yang berperilaku baik, jujur, dan suka menolong dikatakan sebagai orang yang memiliki karakter baik/mulia.

Pencetus pendidikan karakter di Indonesia telah menyusun 9 pilar karakter mulia yang selayaknya dijaikan acuan dalam pendidikan karakter, baik disekolah maupun di luar sekolah, yaitu sebagai berikut: 1) Cinta Allah dan kebenaran, 2) Tanggung jawab, disiplin, dan mandiri, 3) Amanah, 4) Hormat dan santun, 5) Kasih sayang, peduli, dan kerja sama, 6) Percaya diri, kreatif, dan pantang menyerah, 7) adil dan berjiwa kepemimpinan, 8) Baik dan rendah hati, 9) Toleran dan cinta damai.

\section{Konsep Metode Bercerita}

Metode bercerita adalah salah satu metode yang digunakan dalam pembelajaran anak usia dini. "Metode bercerita merupakan salah satu pemberian pengalaman belajar bagi anak dengan membawakan cerita kepada anak secara lisan". (Moeslichatoen, 2004:154). "Bercerita juga dapat dijadikan metode untuk menyampaikan nilai-nilai yang berlaku dalam masyarakat". (Otib Satibi Hidayat, 2005:4.12).

Selain itu bercerita merupakan kegiatan yang dapat menciptakan suasana yang menyenangkan juga dapat mengundang dan merangsang proses kognisi khususnya aktivitas berimajinasi, dapat mengembangkan kesiapan dasar bagi perkembangan bahasa dan literacy serta dapat berfungsi untuk membangun hubungan yang akrab (Solehudin, 2000:90).

Senada dengan pendapat di atas, (Yuri, 1958:40) menyatakan bahwa "bercerita merupakan jenis permainan bertujuan untuk mengembangkan kemampuan berbahasa, berpikir logis, pengaturan diri, pertimbangan memori yang mendalam, pertimbangan perilaku serta pola umum dan makna cerita (karakter, ide, konsep, dan peristiwa penting yang bermanfaat)".
Metode bercerita ialah suatu cara yang digunakan dalam menceritakan kisah-kisah yang dapat menyentuh hati manusia dan mendidik perasaan keimanan. Seperti mengungkap perasaan khauf, ridha, dan cinta, yang melibatkan pembicaraan dan pendengar.

\section{Konse p Pendidikan Anak Usia Dini}

Pengertian anak usia dini pendidikan anak usia dini (PAUD) adalah suatu proses pembinaan tumbuh kembang anak sejak lahir hingga enam tahun secara menyeluruh, yang mencakup aspek fisik dan nonfisik dengan memberikan rangsangan bagi perkembangan jasmani, rohani (moral dan spiritual), motorik, akal piker, emosional, dan sosial yang tepat dan benar agar anak dapat tumbuh dan berkembang secara optimal. Adapun upaya yang dilakukan mencakup stimulasi intelektual, pemeliharaan kesehatan, pemberian nutrisi, dan penyediaan kesempatan-kesempatan yang luas untuk mengeksplorasi dan belajar secara aktif. (Aqib Zainal, 2011:13)

Sedangkan menurut undang-undang Sistem Pendidikan Nasional No. 20 Tahun 2003, pendidikan anak usia dini adalah suatu upaya pembinaan yang ditujukan kepada anak sejak lahir sampai usia 6 tahun yang dilakukan melalui pemberian rangsangan pendidikan untuk membantu pertumbuhan dan perkembangan jasmani dan rohani agar anak memiliki kesiapan dalam memasuki pendidikan lebih lanjut.

Pendidikan anak usia dini (paud) proses pembinaan tumbuh kembang anak usia lahir hingga enam tahun secara menyeluruh, yang mencakup aspek fisik dan non fisik, dengan memberikan rangsangan bagi perkembangan jasmani, rohani , (moral dan spiritual), motorik, akal pikir, emosional, dan sosial yang tepat agar anak dapat tumbuh dan berkembang secara optimal.

\section{Hasil Pene litian dan Pembahasan}


Hasil penelitian mengacu pada tujuan penelitian yang mendeskripsikan tiga rumusan masalah sebagai berikut: (a) Penerapan pendidikan akhlak mulia dalam menge mbangkan karakter pada anak usia dini di paud an nuur, (b) Prosedur pembelajaran penggunaan metode bercerita dalam mengembangkan karakter pada anak usia dini di paud an-nuur, (c) Faktor pendukung dan faktor penghambat penerapan pendidikan akhlak mulia dalam menge mbangkan karakter pada anak usia dini di PAUD A-Nuur. Ketiga hasil penelitan tersebut dipaparkan sebagai berikut:

\section{Interpre tas i pe laks anaan penerapan pendidikan akhlak mulia dalam mengembangkan karakter pada anak usia dini \\ Berdasarkan observasi dan} wawancara terhadap tutor pendidikan anak usia dini yang peneliti lakukan menjelaskan, bahwa pendidikan yang paling penting pada anak adalah pembentukkan kepribadian yaitu pendidikan mengenai sikap dan tingkah laku, dan akhlak. Mengenai sikap dan tingkah laku alasannya, yaitu untuk membekali anak agar mengerti akhlak dan norma-norma berdasarkan agama, serta melakukan pengarahan dengan menjelaskan mengenai sikap dan tingkah laku yang baik kepada warga belajar sikap dan tingkah laku merupakan faktor yang penting yang harus diajarkan kepada anak sejak usia dini agar mempunyai sikap dan bertingkah laku yang baik, sopan santun, bertutur kata yang baik.

Dari data deskripsi diatas menunjukkan hasil penerapan pendidikan akhlak mulia pada penanaman aspek sikap terdapat hubungan yang relevan antara pelaksanaan penerapan pendidikan akhlak yang diberikan tutor disekolah dengan pengertian pendidikan akhlak, penerapan pendidikan akhlak yang ditanamkan pada anak usia dini dalam berakhlakul karimah, menekankan pada keteladanan, berperilaku yang baik, pembiasaan disiplin yang dilakukan sejak kecil dan berlangsung secara kontinyu, dengan demikian, apa yang dilihat, didengar, dirasakan dan dikerjakan oleh warga belajar dapat membentuk kepribadian mereka secara utuh dan melekat dalam jiwa anak dimasa mendatang

\section{Interpretasi prosedur pembelajaran penggunaan metode bercerita dalam mengembangkan karakter pada anak usia dini}

Berdasarkan observasi dan wawancara terhadap tutor pendidikan anak usia dini yang peneliti lakukan menjelaskan, bahwa dalam proses pembelajaran terdapat perencanaan penerapan pendidikan akhlak melalui tema cerita yang biasanya dibuat langsung oleh setiap tutor kelas masing-masing sehari sebelum kegiatan pembelajaran di mulai, tutor mempersiapkan media yang akan digunakan dan memilih cerita yang akan diceritakan disesuaikan dengan tema, kebutuhan dan keadaan kelas masingmasing. Pelaksanaan pe mbelajaran tutor melakukan persiapan bercerita dengan membawa media bercerita mempersiapkan siswa dengan bernyanyi dan bertepuk pola, agar siswanya merasa senang dan konsentrasi dalam mendengarkan kegiatan bercerita, evaluasi pembelajaran yang dilakukan tutor setiap hari. Tujuan dilaksanakannya kegiatan bercerita ini untuk merangsang imajinasi dan kreativitas warga belajar, memberikan suasana yang segar dan menyenangkan bagi anak-anak,

Dari data deskripsi diatas menunjukkan hasil prosedur pembelajaran penggunaan metode bercerita pada anak usia dini terdapat hubungan yang relevan dengan konsep metode bercerita yang menggambarkan kegiatan yang menyenagkan dan dapat merangsang imajinasi siswa. Dalam bahasa lain terdapat hubungan yang relevan pada tahap perencanaan, pelaksanaan dan evaluasi pada pembelajaran penerapan 
pendidikan akhlak melalui metode bercerita pengelola dan tutor merencanakan aspek-aspek penting yang harus sudah dipersiapkan sehari sebelum kegiatan pembelajaran dimulai,kemudian dilaksanakan dan dievaluasi

\section{Faktor pendukung dan faktor penghambat penerapan pendidikan akhlak mulia dalam mengembangkan karakter pada anak usia dini}

Berdasarkan observasi dan wawancara terhadap tutor pendidikan anak usia dini yang peneliti lakukan menjelaskan, bahwa ada faktor pendukung dalam penerapan pendidikan akhlak yaitu kerjasama antara tutor dan kepala sekolah (pengelola) pada penerapan pendidikan akhlak mulia dalam mengembangkan karakter pada anak usia dini sudah terjalin dengan baik, kompetensi para tutor memiliki tingkat pendidikan yang sesuai dengan kompetensi pendidik, sehingga mereka sudah memiliki kemampuan yang baik dalam melakukan kegiatan pembelajaran. Tutor merupakan faktor utama dalam memdukung pembelajaran nilai-nilai akhlak, sarana dan prasarana sangat dibutuhkan untuk mendukung pengalaman siswa belajar Sarana dan prasarana dalam kegiatan pembelajaran sudah cukup memadai seperti alat permainan edukatif yang dipergunakan baik yang didalam ruangan dan di luar ruangan. Walaupun belum begitu komplit.

Faktor penghambat yaitu manajemen waktu yang terbatas ketika anak berada disekolah, dari sikap anak yang suka manja, tidak mau mendengarkan nasehat guru disekolah terkadang membantah, dan anak susah diberi pengarahan, jika dirumah menonton televisi kadang anak berperilaku kurang baik karena suka meniru seperti yang ada di televisi, kelakuan itu dibawa sampai ke sekolah, dan faktor dari sikap orang tua yang kurang memotivasi anak
Dari data deskripsi diatas menunjukkan faktor pendukung dan faktor penghambat penerapan pendidikan akhlak mulia pada anak usia dini terdapat beberapa dukungan positif dan hambatan yang tidak terlalu kuat, jika diberikan penyuluhan kepada orang tua siswa akan pentingnya pendidikan akhlak dan pengertian yang rutin kepada siswa. Dalam bahasa lain terdapat hasil yang positif dalam faktor pendukung pada penerapan pendidikan akhlak yaitu kerjasama antara tutor dan kepala sekolah (pengelola) pada penerapan pendidikan akhlak mulia dalam mengembangkan karakter pada anak usia dini sudah terjalin dengan baik, serta sarana dan prasarana yang sudah ada, hambatan yang tidak terlalu kuat, pada siswa dan orang tua jika diberikan penyuluhan akan pentingnya pendidikan akhlak dan pengertian yang rutin kepada siswa.

\section{E. Kesimpulan dan Saran}

Penerapan pendiikan akhlak mulia sangat penting sekali diterapkan pada anak usia dini dalam berakhlakul karimah, yang menekankan pada keteladanan, berperilaku yang baik, pembiasaan disiplin dilakukan sejak kecil dan berlangsung secara kontinyu, dengan demikian, apa yang dilihat, didengar, dirasakan dan diimplementasikan oleh warga belajar dapat membentuk kepribadian mereka secara utuh dan melekat dalam jiwa anak dimasa mendatang.

Saran yang dikemukakan berdasarkan hasil penelitian ditjukan kepada pengelola PAUD An-Nur untuk meningkatkan kegiatan kajian tentang pendidikan akhlak mulia yang melibatkan semua tutor dan orang tua. Selanjutnya bagi tutor PAUD An-Nur sebaiknya mempertahnakn pola pembelajaran yang telah dolakukan selama ini dan terus meningkatjan mutu pe mbelajaran terutama berkenaan dengan pembelajaran pemodelan tentang akhlak mulia melalui metoda bercerita. 


\section{Daftar Pustaka}

Arikunto, S. (2006) Prosedur Penelitian Suatu Pendekatan dan Praktek (Edisi Revisi VI). Jakarta; Rineka Cipta

Afifudin dan Saebani, B.A. (2009). Metodologi Penelitian Kualitatif, Bandung; Pustaka Setia.

Al-Qur'an Terjemah Indonesia. (2005). Jakarta: depag RI

Aqib Zainal. (2011). Pedoman Teknis Penyelenggaraan Pendidikan Anak Usia Dini (PAUD). Bandung; CV. Nuansa Aulia

Azra Azyumardi, (2002). Buku Teks Pendididikan Agama Islam, Departemen Agama RI

Barsowi dan Suwandi. (2008). Memahami Penelitian Kualitatif. Jakarta: Rineka Cipta

Dahlan. (2001). Model-model Mengajar beberapa Alternatif Interaksi belajar Mengajar. Bandung: CV. Diponegoro

Gunawan Tuti. (2007). Teknik Bercerita. Jakarta: PT Penerbitan Sarana Bobo

Hatimah,I. (2003). Strategi Metode Pembelajaran. Bandung: CV. Andira

Maleong, L.J. (2007). Metodologi Penelitian Kualitatif Edisi Revisi. Bandung; PT Remaja RosdaKarya.

Mulyasa. E. (2011). Manajemen Pendidikan Karakter. Jakarta: PT Bumi Aksara

Majid Abdul \& Andayani Dian, (2012). Pendidikan Karakter Bandung; PT Remaja Rosda Karya.

Mansur. (2005). Membina Moral Akhlak. Jakarta: Kalam Mulia.

Mustofa, (2005). Membina Moral dan Akhlak, Jakarta: Kalam Mulia.

Moeslichatoen. (2004). Metode Pengajaran di Taman Kanak-Kanak, Jakarta: Rineka Cipta

Rakhmat, Dj. (1987) Islam Alternatif. Bandung : Mizan

Sadeli Sukanda (1989). Bimbingan (Akhlakl yang Mulia) Bandung; Yayasan Pendidikan Islam "AshSholieh"
Sugiyono. (2008). Metode Penelitian kuantitatif, Kualitatif dan $R \& D$. Bandung; Alfabeta.

Sudjana Djuju. (2009). Pendidikan Luar Sekolah Wawasan Sejarah Perkembangan Falsafah dan Teori Pendukung Azas. Bandung: Nusantara Press.

Suryabarata. S. (2009). Metodologi Penelitian. Jakarta; PT. Raja Grafindo Persada.

Tafsir Ahmad. (2010) Ilmu Pendidikan Dalam Perspektif Islam. Bandung: PT Remaja Rosda Karya.

Tafsir Ahmad. (1998) Pendidikan Agama Dalam Keluarga. Bandung: PT Remaja Rosda Karya

Universitas Pendidikan Indonesia, (2012). Pedoman Penulisan Karya Ilmiah, Bandung: UPI Press

Universitas Pendidikan Indonesia, (2009). Islam Tuntunan dan Pedoman Hidup, Bandung: Value Press

Yudha Andi. (2007). Cara Pintar Mendongeng. Bandung: PT Mizan Bunaya Kreatif. 